Editors' Note: In "Clinical Reasoning: A young woman with respiratory failure, hearing loss, and paraplegia," Ntranos et al. discussed the case of a patient with lesions in the globus pallidi, spinal cord, and cochleae in the setting of opioid overdose and respiratory failure. They concluded that the patient's neurologic syndrome was related to hypoxia. Commenting on this article, Dr. Berg asks the authors whether they considered the possibility of methylmalonic acidemia (MMA) as a potential underlying susceptibility factor because the lesions on the patient's MRI in the globus pallidi are characteristic of MMA. He suggests testing the patient's urine for MMA and blood for B12 level. Dr. Ntranos confirms that they checked the methylmalonic acid serum level, which was undetectable. Commenting on the same article, Drs. Bhatt and Adams propose that the patient's cochlear injury is related directly to opiate toxicity rather than hypoxia. Ntranos et al. stand by their hypothesis, explaining that the patient referenced by Bhatt and Adams was using multiple toxic substances for which the composition is unknown and that the presence of opiate receptors in cochlear cells does not mean that their stimulation will cause neurotoxicity. They suggest that additional research is needed to determine the direct effect of opiate use in cochlear cells.

-Chafic Karam, MD, and Robert C. Griggs, MD until the stress of the opioid overdose or an acquired form due to severe B12 deficiency. If the authors did not check, it may be worthwhile to perform a followup test on the patient's urine sample for MMA and blood for B12 level. Even if results are normal, I wonder whether the patient has an underlying energy metabolism disorder that clinically manifested with the acute stressor given the particular combination of the lesions.

1. Ntranos A, Shoirah H, Dhamoon MS, et al. Clinical Reasoning: a young woman with respiratory failure, hearing loss, and paraplegia. Neurology 2017;88:e78-e84.

(C) 2017 American Academy of Neurology

\section{AUTHOR RESPONSE: CLINICAL REASONING: A YOUNG WOMAN WITH RESPIRATORY FAILURE, HEARING LOSS, AND PARAPLEGIA}

Achilles Ntranos, New York: I thank Dr. Berg for the thoughtful comments on our article. ${ }^{1}$ Methylmalonic acidemia is indeed an important consideration for this case. We included a methylmalonic acid serum level in our initial workup, which was undetectable.

1. Ntranos A, Shoirah H, Dhamoon MS, et al. Clinical Reasoning: a young woman with respiratory failure, hearing loss, and paraplegia. Neurology 2017;88:e78-e84.

(C) 2017 American Academy of Neurology

\section{LETTER RE: CLINICAL REASONING: A YOUNG WOMAN WITH RESPIRATORY FAILURE, HEARING LOSS, AND PARAPLEGIA}

Michel J. Berg, Rochester, NY: I read with interest the case presented by Ntranos et al. ${ }^{1}$ of acute-onset bilateral lesions in the globus pallidi, hearing loss (possible cochlear dysfunction), and upper thoracic anterior spinal cord lesion in a patient with an opioid/ acetaminophen overdose and possible transient hypoxia. Did the authors consider the possibility of methylmalonic acidemia (MMA) as a potential underlying susceptibility factor? The lesions on the patient's MRI in the globus pallidi are characteristic of MMA. There are several possibilities, including an unrecognized minor mutation in the MMA pathway resulting in partial loss of function that was subclinical

\section{C2017 American Academy of Neurology}

Nirav Bhatt, David Adams, Miami, FL: Ntranos et al. ${ }^{1}$ presented a case of a 35-year-old woman with acute respiratory failure, hearing loss, and paraplegia. After discussing the differential diagnosis, they concluded that the likely cause of her symptoms was diffuse hypoxic injury of the involved structures.

While global hypoxia can cause bilateral basal ganglia infarctions and anterior spinal artery syndrome, it is a rather unlikely cause of bilateral cochlear injury. Contrariwise, there is substantial evidence to support 
direct cochlear toxicity as a result of chronic opioid use and opioid overdose. ${ }^{2}$ Animal studies have shown the presence of opioid receptors in the cochlea, ${ }^{3}$ and overstimulation of kappa receptors decreasing afferent activity from the cochlea may play a role in mediating this direct toxicity.

The patient described was confirmed to have an opioid overdose, and her bilateral hearing loss may be the result of direct cochlear injury as opposed to hypoxic injury, the latter mechanism being poorly supported in the literature. Thus, we propose 2 separate mechanisms from opioid overdose leading to the patient's constellation of symptoms: (1) direct cochlear toxicity leading to bilateral hearing loss and (2) hypoxemia leading to the anterior spinal artery syndrome and bilateral globus pallidal infarctions.

1. Ntranos A, Shoirah H, Dhamoon MS, et al. Clinical Reasoning: a young woman with respiratory failure, hearing loss, and paraplegia. Neurology 2017;88:e78-e84.

2. Schweitzer VG, Darrat I, Stach BA, Gray E. Sudden bilateral sensorineural hearing loss following polysubstance narcotic overdose. J Am Acad Audiol 2011;22:208-214.

3. Jongkamonwiwat N, Phansuwan-Pujito P, Casalotti SO, et al. The existence of opioid receptors in the cochlea of Guinea pigs. Eur J Neurosci 2006;23:2701-2711.

(C) 2017 American Academy of Neurology

\section{AUTHOR RESPONSE: CLINICAL REASONING: A YOUNG WOMAN WITH RESPIRATORY FAILURE, HEARING LOSS, AND PARAPLEGIA}

Achilles Ntranos, Hazem Shoirah, Mandip S. Dhamoon, New York; David Hahn, Greenwich, CT; Thomas P. Naidich, Susan Shin, New York: We thank Drs. Bhatt and Adams for the thoughtful comment on our article. ${ }^{1}$ Hypoxia affects cochlear function in many ways, ${ }^{2-5}$ including a rapid decline in both endocochlear and other cochlear potentials (i.e., cochlear microphonic, distortion-product otoacoustic emission, and compound action potential), ${ }^{6,7}$ as well as inducing histologic and cellular changes. ${ }^{8}$ Moreover, hypoxia, in the form of apneic spells, is a significant clinical predictor of newborn sensorineural hearing loss. ${ }^{\text {? }}$

A cytotoxic effect of opiate use is an important consideration and could potentially have contributed to the patient's hearing loss. ${ }^{1}$ Although opiates can have a direct cytotoxic effect in cells, the causal relationship to hearing loss cannot be established because the patient referenced by Bhatt and Adams was using multiple toxic substances (heroin, alcohol, crack cocaine, and benzodiazepines) for which the composition is unknown. ${ }^{10}$

The presence of opiate receptors in cochlear cells does not mean that their stimulation will cause neurotoxicity. A lack of correlation between opiate-induced toxicity and their ability to activate opiate receptors was previously identified. ${ }^{11}$ Further research is needed to determine the direct effect of opiate use in cochlear cells.

The most likely mechanism of cochlear injury in the reported patient was the prolonged global hypoxic state induced by oxycodone overdose. ${ }^{1}$

1. Ntranos A, Shoirah H, Dhamoon MS, et al. Clinical Reasoning: a young woman with respiratory failure, hearing loss, and paraplegia. Neurology 2017;88:e78-e84.

2. Tabuchi K, Nishimura B, Tanaka S, et al. Ischemiareperfusion injury of the cochlea: pharmacological strategies for cochlear protection and implications of glutamate and reactive oxygen species. Curr Neuropharmacol 2010;8: $128-134$.

3. Thalmann R, Miyoshi T, Thalmann I. The influence of ischemia upon the energy reserves of inner ear tissues. Laryngoscope 1972;82:2249-2272.

4. Haupt H, Scheibe F, Ludwig C. Changes in cochlear oxygenation, microcirculation and auditory function during prolonged general hypoxia. Eur Arch Otorhinolaryngol 1993;250:396-400.

5. Fan D, Ren H, Danzeng D, Li H, Wang P. Influence of high-altitude hypoxic environments on the survival of cochlear hair cells and spiral ganglion neurons in rats. Biomed Rep 2016;5:681-685.

6. Tabuchi K, Tsuji S, Fujihira K, et al. Outer hair cells functionally and structurally deteriorate during reperfusion. Hear Res 2002;173:153-163.

7. Pierson MG, Moller AR. Corresponding effects of hypoxia on the cochlear microphonic and the compound action potential. Hear Res 1982;6:83-101.

8. Perlman HB, Kimura R, Fernandez C. Experiments on temporary obstruction of the internal auditory artery. Laryngoscope 1959;69:591-613.

9. Abramovich SJ, Gregory S, Slemick M, Stewart A. Hearing loss in very low birthweight infants treated with neonatal intensive care. Arch Dis Child 1979;54: 421-426.

10. Schweitzer VG, Darrat I, Stach BA, Gray E. Sudden bilateral sensorineural hearing loss following polysubstance narcotic overdose. J Am Acad Audiol 2011;22:208-214.

11. Ren XH, Zhao J, Pu L, et al. Differential neurotoxicity of etorphine-like opiates: lack of correlation with their ability to activate opiate receptors. Toxicon 1998;36:735-743.

(C) 2017 American Academy of Neurology 


\section{CORRECTION}

Short-term clinical outcomes for stages of NIA-AA preclinical Alzheimer disease

In the article "Short-term clinical outcomes for stages of NIA-AA preclinical Alzheimer disease" by D.S. Knopman et al., ${ }^{1}$ there are errors in table 2 for values entered under columns "Stage 2" and "Stage 3." Please see the corrected table below.

\section{REFERENCE}

1. Knopman DS, Jack CR Jr, Wiste HJ, et al. Short-term clinical outcomes for stages of NIA-AA preclinical Alzheimer disease. Neurology 2012;78:1576-1582.

\section{Table 2 Descriptive characteristics of participants by preclinical AD stage (with corrected values in boldface)}

\begin{tabular}{|c|c|c|c|c|c|}
\hline \multirow[b]{2}{*}{ Characteristic } & \multicolumn{5}{|c|}{ Stage defined by imaging and cognitive assessment ${ }^{a}$} \\
\hline & $\begin{array}{l}\text { Stage } 0 \\
(\mathrm{n}=127)\end{array}$ & $\begin{array}{l}\text { Stage } 1 \\
(n=44)\end{array}$ & $\begin{array}{l}\text { Stage } 2 \\
(n=39)\end{array}$ & $\begin{array}{l}\text { Stage } 3 \\
(n=7)\end{array}$ & $\begin{array}{l}\text { SNAP group } \\
(n=69)\end{array}$ \\
\hline $\begin{array}{l}\text { Age, y, median } \\
\text { (IQR) }\end{array}$ & $77(74,80)$ & $80(75,82)$ & $80(78,82)$ & $81(80,82)$ & $81(76,84)$ \\
\hline Female, $n(\%)$ & $62(49)$ & $20(45)$ & $15(38)$ & 2 (29) & $26(38)$ \\
\hline $\begin{array}{l}\text { Education, y, } \\
\text { median (IQR) }\end{array}$ & $14(12,16)$ & $14(12,16)$ & $15(12,18)$ & $14(12,16)$ & $14(12,16)$ \\
\hline $\begin{array}{l}\text { APOE } \varepsilon 4 \\
\text { carrier, } \mathrm{n}(\%)\end{array}$ & $31(24)$ & 15 (34) & $16(41)$ & $5(71)$ & $8(12)$ \\
\hline $\begin{array}{l}\text { MMSE score, } \\
\text { median (IQR) }\end{array}$ & $28(28,29)$ & $28(27,29)$ & $28(27,29)$ & $27(26,28)$ & $28(27,29)$ \\
\hline \multicolumn{6}{|l|}{$\begin{array}{l}\text { No. of follow-up } \\
\text { visits, } n(\%)\end{array}$} \\
\hline One & $96(76)$ & $38(86)$ & $33(85)$ & $7(100)$ & $56(81)$ \\
\hline Two & $26(20)$ & $4(9)$ & $3(8)$ & $0(0)$ & 8 (12) \\
\hline Three & $3(2)$ & $2(5)$ & $3(8)$ & $0(0)$ & $3(4)$ \\
\hline Four & $2(2)$ & $0(0)$ & $0(0)$ & $0(0)$ & 2 (3) \\
\hline $\begin{array}{l}\text { Years of follow-up, } \\
\text { median (range) }\end{array}$ & $1.3(1.1,5.1)$ & $1.3(1.2,3.9)$ & $1.3(1.1,4.1)$ & $1.3(1.2,1.5)$ & $1.3(1.1,5.1)$ \\
\hline $\begin{array}{l}\mathrm{MCl} / \text { dementia } \\
\text { diagnosis at } 1 \\
\text { year, } \mathrm{n}(\%)\end{array}$ & $6(5)$ & $5(11)$ & $8(21)$ & $3(43)$ & 7 (10) \\
\hline \multicolumn{6}{|c|}{ Cognitive $z$ scores, median (IQR) ${ }^{b}$} \\
\hline Global & $0.71(0.18,1.35)$ & $0.47(-0.00,1.29)$ & $0.34(-0.27,0.82)$ & $-1.22(-1.34,-1.00)$ & $0.47(-0.30,1.11)$ \\
\hline Memory & $0.71(0.13,1.33)$ & $0.75(-0.16,1.54)$ & $0.40(-0.31,0.78)$ & $-1.36(-1.78,-1.13)$ & $0.36(-0.26,1.22)$ \\
\hline Language & $0.49(0.04,1.09)$ & $0.37(-0.40,0.90)$ & $0.19(-0.33,0.80)$ & $-0.90(-1.02,-0.42)$ & $0.27(-0.38,1.07)$ \\
\hline Executive & $0.66(0.10,1.09)$ & $0.44(-0.17,1.13)$ & $0.12(-0.38,0.92)$ & $-0.64(-0.92,-0.03)$ & $0.03(-0.48,0.96)$ \\
\hline Visuospatial & $0.63(0.03,1.18)$ & $0.62(0.24,1.39)$ & $0.44(-0.10,0.85)$ & $-1.43(-1.60,-0.77)$ & $0.35(-0.49,0.89)$ \\
\hline $\begin{array}{l}\text { PiB ratio, } \\
\text { median (IQR) }\end{array}$ & $1.33(1.29,1.38)$ & $1.86(1.64,2.11)$ & $1.93(1.67,2.29)$ & $2.16(1.90,2.29)$ & $1.34(1.30,1.39)$ \\
\hline $\begin{array}{l}\text { FDG ratio, } \\
\text { median (IQR) }\end{array}$ & $1.46(1.39,1.52)$ & $1.43(1.39,1.53)$ & $1.27(1.21,1.30)$ & $1.23(1.17,1.30)$ & $1.28(1.25,1.33)$ \\
\hline $\begin{array}{l}\text { Adjusted } \\
\text { hippocampal } \\
\text { volume, } \\
\text { median (IQR) }\end{array}$ & $\begin{array}{l}0.39 \\
(-0.19,0.84)\end{array}$ & $0.36(-0.09,0.77)$ & $-0.46(-0.97,0.10)$ & $-0.87(-1.07,-0.71)$ & $\begin{array}{l}-0.54 \\
(-0.82,-0.14)\end{array}$ \\
\hline
\end{tabular}

Abbreviations: $A D=$ Alzheimer disease; $C N=$ cognitively normal; FDG = fluorodeoxyglucose; $I Q R=$ interquartile range; $\mathrm{MCl}=$ mild cognitive impairment; $\mathrm{MCSA}=$ Mayo Clinic Study of Aging; MMSE = Mini-Mental State Examination; PiB = Pittsburgh compound $\mathrm{B}$.

a Stage 0, all biomarkers normal; stage 1, abnormal PiB-PET; stage 2, abnormal PiB-PET and falling abnormal on at least one neurodegeneration biomarker; stage 3, abnormal PiB-PET, neurodegeneration and cognitive z score; SNAP, suspected non-Alzheimer pathway, where at least one neurodegeneration biomarker is abnormal with normal PiBPET with or without abnormal cognition.

${ }^{\mathrm{b}}$ The median global cognitive $z$ scores are $>0$ for the study group, which reflects their volunteer nature and the fact that about three-fourths of subjects had had one or more cognitive testing sessions before the PET baseline visit. 


\section{Neurology}

\section{Short-term clinical outcomes for stages of NIA-AA preclinical Alzheimer disease Neurology 2017;89;980}

DOI 10.1212/WNL.0000000000004318

This information is current as of August 28, 2017

\section{Updated Information \&} Services

References

Permissions \& Licensing

Reprints including high resolution figures, can be found at: http://n.neurology.org/content/89/9/980.full

This article cites 1 articles, 1 of which you can access for free at: http://n.neurology.org/content/89/9/980.full\#ref-list-1

Information about reproducing this article in parts (figures,tables) or in its entirety can be found online at:

http://www.neurology.org/about/about_the_journal\#permissions

Information about ordering reprints can be found online:

http://n.neurology.org/subscribers/advertise

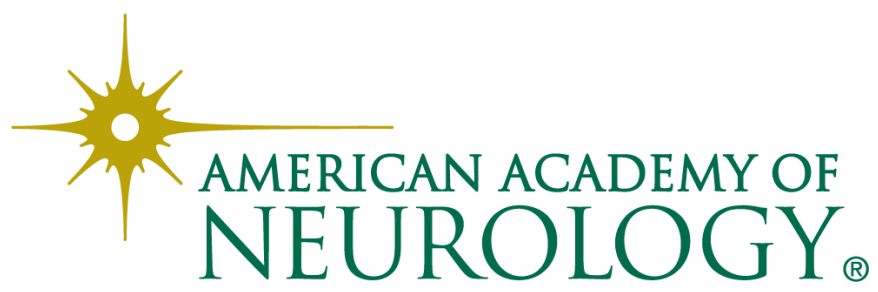

